\title{
Constraints on Geological Strain Rates: Arguments From Finite Strain States of Naturally Deformed Rocks
}

\author{
O. A. Pfiffner' and J. G. Ramsay
}

Geologisches Institul, Eidgenoessischen Technischen Hochschule-Zentrum, CH-8092 Zurich, Switzerland

\begin{abstract}
A summary of known finite strain states is presented; longitudinal strains $(1+e)$ as measured in many rocks often range from 1 to 40 and 1 to 0.025 . The time span available to produce such measurable strains in young orogenic zones seems to be less than $10 \mathrm{~m}$.y., possibly less than $1 \mathrm{~m}$.y., which constrains conventional strain rates into the range of $10^{-13} \mathrm{~s}^{-1}$ to $10^{-15} \mathrm{~s}^{-1}$. For both pure and simple shear (the most efficient way and a much less efficient way to accumulate incremental strains, respectively) the ellipticity of the finite strain ellipse increases in a nonlinear manner. Finite strain variations in adjacent layers, which give rise to features such as cleavage refraction, arise with only slight differences in the strain rates within these layers.
\end{abstract}

\section{INTRODUCTION}

The amount of data on the rates at which natural rock deformations take place is rather small. That which is quoted most frequently is based on geodetic surveys in the vicinity of the San Andreas Fault [Whitten, 1956]. Triangulation carried out over a period of 20 years showed systematic displacements that indicated that any initially rectangular block would gradually become changed into a parallelogram with a change of azimuth of 1 second of arc every 10 years. From this observation it is possible to conclude that if the deformation is taking place by simple shear parallel to the fault, the shear strain rate $\dot{\gamma}$ is $1.5 \times 10^{-13} \mathrm{~s}^{-1}$ and the principal extension rates $\dot{e}_{1}=$ $-\dot{e}_{2}\left(\dot{e}_{1}=\dot{\gamma} / 2\right.$ in simple shear) is $7.5 \times 10^{-14} \mathrm{~s}^{-1}$. However, the surface movements in these zones might not be truely representative of the deeper crustal levels [Johnston et al., 1977].

Another method of calculating strain rate has been based on the isostatic adjustment that has taken place as a result of removal of bodies of ice or water from the earth's surface [Crittenden, 1967]. Hicks and Shofnos [1965] used measurements of uplifts in Glacier Bay, Alaska, indicating strain rates of from $0.5 \times 10^{-14}$ to $2.5 \times 10^{-14} \mathrm{~s}^{-1}$.

Heard [1976] suggested that strain rates could be estimated from displacement rates of seafloor spreading and that values generally lie between $10^{-13}$ and $10^{-14} \mathrm{~s}^{-1}$. However, before such a calculation can be made, some specific model for progressive deformation of the crust must be selected because different strain increment models dissipate the plate displacements at different strain rates.

In the European Alpine orogenic belt it seems likely that $150-400 \mathrm{~km}$ of crustal shortening has taken place [Trümpy, 1972, 1973; Gilluly, 1972] over a time period from the Upper Cretaceous to the Oligocene. It seems to us difficult to use this data to determine the average strain rate as proposed by Heard [1976] without presupposing some specific model for the strain history of the plate collision zone.

The aim of this paper is to attack the strain rate problem from a new viewpoint. Structural geologists have collected much data on finite strains in naturally deformed rocks. In certain regions we have some knowledge on the time taken for

\footnotetext{
${ }^{1}$ Now at Institut de Geologie, Université de Neuchâtel, CH-2000 Neuchâtel, Switzerland.

Copyright $\odot 1982$ by the American Geophysical Union.
}

the total deformation to have taken place. In the sections which follow we discuss the possibility of combining this data to arrive at values of the geologically representative average strain rate that could have produced the observed finite strain.

\section{STRAIN RATE}

Strain rate is defined as the proportional change in length of a line element in an infinitesimal time interval, which in the geological sciences is a unit of ls duration. For example, if a line extends by one tenth $\left(10^{-1}\right)$ of its length prior to the strain increment in 1s, the strain rate is defined as

$$
\dot{e}=10^{-1} \mathrm{~s}^{-1}
$$

Two types of strain rates may be defined [Nadai, 1950, p. 74]: The conventional strain rate, where the length prior to the strain increments is always chosen the same $\left(l_{0}\right)$,

$$
\dot{e}_{i}=d l_{i} / l_{0}=\text { const }
$$

and the natural strain rate, where the length prior to the strain increments includes the changes in length of the preceding increments,

$$
\dot{e}_{i}=\frac{d l_{i}}{l_{0}+d l_{1}+d l_{2}+\cdots+d l_{i-1}}
$$

It will be seen from the above equations that for constant incremental length changes $d l_{i}$ the natural strain rate $\dot{e}$ will decrease in the course of the deformation history, whereas the conventional strain rate $\dot{e}$ will remain constant. Since a constant strain rate relates better to the concept of steady flow of rocks, we use conventional strain rate throughout this paper. How can strain rate per second be derived from finite length changes which have taken place over a longer period of time than $1 \mathrm{~s}$ ? We solve this problem by superposing strain increments and comparing the resulting finite strains with the incremental strains (i.e., the strain rate). Under these circumstances the finite elongation $1+e$ will increase in a linear or nonlinear manner, depending upon whether one uses natural or conventional strain rates respectively (cf. Figure 1). Thus, if one simply divides strain $e$ by time $t$ (as proposed by Price [1975]), one determines a natural strain rate which is much larger than a corresponding conventional strain rate producing the same finite strain after the same number of increments.

In steady state flow processes, where identical increments of 


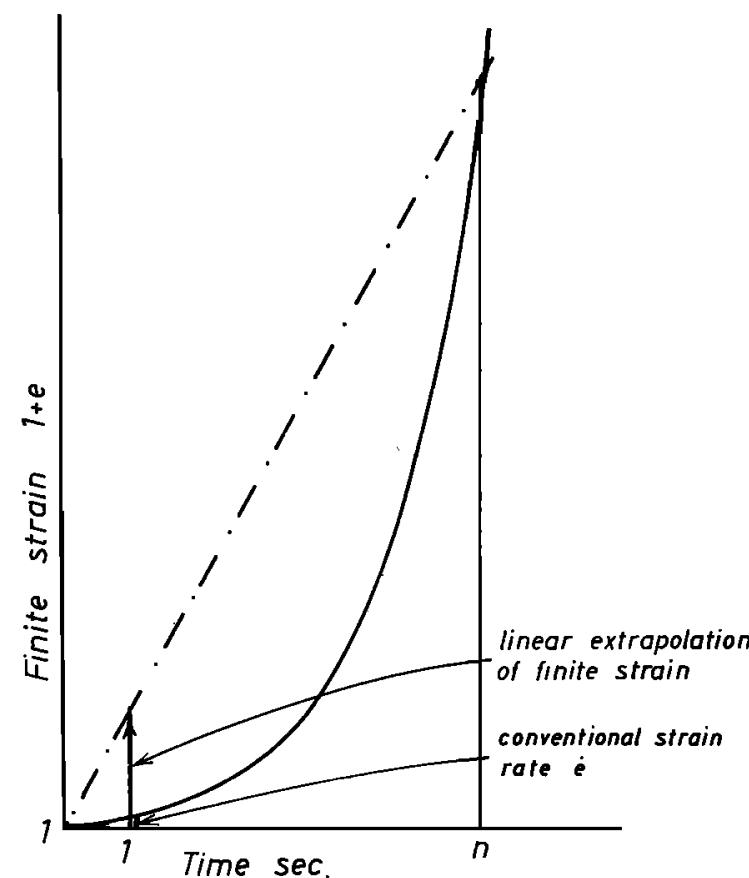

Fig. 1. Growth of finite strain in a time period of $\boldsymbol{n}$ seconds, illustrating the errors resulting from linearly extrapolating the finite strain.

distortion are developed during each second, the changes in longitudinal strain rate along any chosen physical line element in the deforming body vary because the line progressively changes its orientation with respect to the principal axes of strain during the deformation sequence. The incremental length changes then become very complex.

Strain rate is a second-order tensor; to define it completely, we need to specify first three angles defining the spatial orientations of the orthogonal principal strain rate axes with reference to three chosen coordinate reference axes; second, the values of the three principal strain rates $\left(\dot{e}_{1}, \dot{e}_{2}\right.$, and $\left.\dot{e}_{3}\right)$; and third, three rotation rates or vorticities of these principal strain rate directions with respect to the chosen coordinate reference axes $\left(\dot{\omega}_{1}, \dot{\omega}_{2}\right.$, and $\left.\dot{\omega}_{3}\right)$. The values taken by the three vorticities are especially important in controlling the finite strains that are built up during a progressive deformation.

In order to simplify the analysis, yet without loosing relevance to problems of deformation in the crust of the earth, we have made a few assumptions and approximations. We have investigated systems which are those of plane strain, considering that changes in the intermediate strain rate $\dot{e}_{2}$ and vorticities $\dot{\omega}_{1}$ and $\dot{\omega}_{3}$ (around the $\dot{e}_{1}$ and $\dot{e}_{3}$ axes, respectively) can be neglected. We know from our analyses of finite strain that the shapes of strain ellipsoids do not always agree with the plane strain constant volume relationships expressed by

$$
\left(1+e_{2}\right)^{2}=\left(1+e_{1}\right)\left(1+e_{3}\right)
$$

However, many of these ellipsoids can be satisfactorily explained by plane strain under conditions of volume change [Ramsay 1967, p. 162; Ramsey and Wood, 1973; Graham, 1978] or by superposing successive plane strains in a noncoaxial manner [Ramsay, 1967, p. 326].

We are also of the opinion that large-scale displacement and average strain patterns that come about during the forcing together of relatively rigid crustal plates in subduction zones are constrained by geometric boundary conditions such that least differential displacement, and therefore least absolute values of strain occur in directions parallel to plate intersections. Furthermore, many of the local deformations seen in naturally deformed rocks are constrained by local conditions which tend to impose plane strains (block faulting, simple shear zone formation, ideal bedding plane slip during buckle folding in stratified rocks).

In two-dimensional plane strain, which we will examine in detail below, four terms are needed to specify a general steady state flow process:

$\theta$ orientation of the principal strain rate axes from the $x$ and $y$ coordinate directions;

$\dot{e}_{1}, \dot{e}_{2} \quad$ values of the principal strain rates;

$\dot{\omega}$ rotation rate or vorticity of the principal strains.

These four strain rate components are related to the displacement rate components $\dot{v}$ (parallel to $x$ ) and $\nu$ (parallel to $y)$ of all points with coordinates $(x, y)$ in the system (see Figure 2).

The effect of a two-dimensional steady state process is illustrated in Figure 3. An initial body (opqr) is, after a given time $\left(t_{1}\right)$, transformed to a parallelogram shape $\left(o_{1} q_{1} r_{1}\right)$. In this deformed material we now draw a new standard grid (op' $q^{\prime} r^{\prime}$ ) of the same shape as opqr) and allow this to become similarly modified after another interval of time $t_{1}$. Now after a total time $\left(t_{2}=2 t_{1}\right)\left(o p^{\prime} q^{\prime} r^{\prime}\right)$ is transformed into $\left(o p_{1}{ }^{\prime} q_{1}{ }^{\prime} r_{1}{ }^{\prime}\right)$ of identical form to (op, $\left.q_{1} r_{1}\right)$, and $\left(o p_{1} q_{1} r_{1}\right)$ becomes transformed to $\left(o_{2} q_{2} r_{2}\right)$. Thus we are able to transform geometrically an initial marker shape by successive identical incremental steps to develop a large finite strain. Mathematical analysis of sequences like this to compute the properties of the finite strain can be easily handled using a computer to produce the successive matrix products [Ramsay, 1967, pp. 322-332] and to analyze the final displacement geometry in terms of principal finite strains (eigenvalues and eigenvectors of the matrix product) and body rotations [Ramsay and Graham, 1970, p. 790]. In a steady state or constant incremental process it is possible to describe the movements to particles in the deforming medium by a series of path lines (Figure $3 e$ ), and Ramberg $[1975 a, b]$ has shown how an analysis of such particle paths can also be used to establish the geometry of the finite displacement and strain state.

The manner whereby an incremental process builds up a

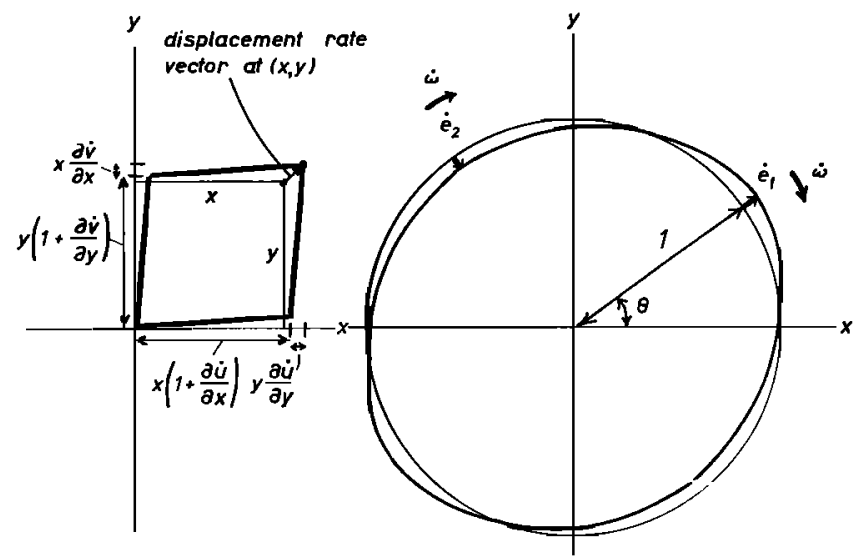

Fig. 2. Relations between displacement rate vector of a point (x, $y$ ) with components $\dot{u}$ and $\dot{v}$ parallel to $x$ and $y$, respectively, displacement rate gradients, strain rate components $\dot{e}_{1}$ and $\dot{e}_{2}$ and vorticity rate $\dot{\omega}$. 


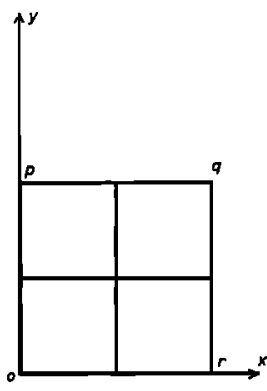

A. Original state

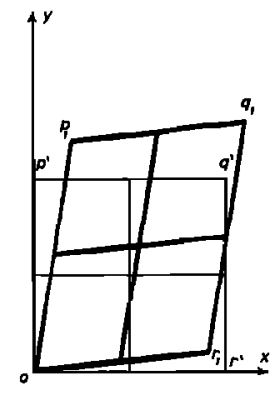

B. Ist increment

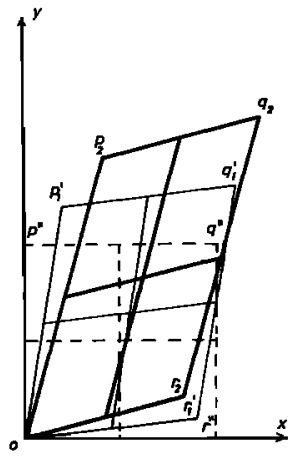

C.2nd increment

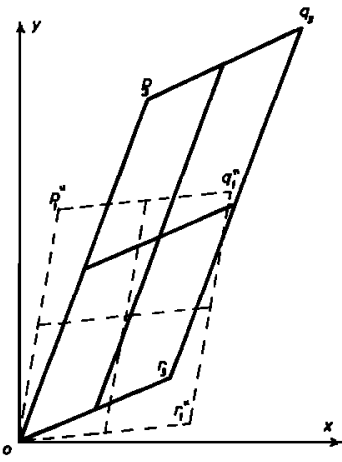

D. 3rd increment

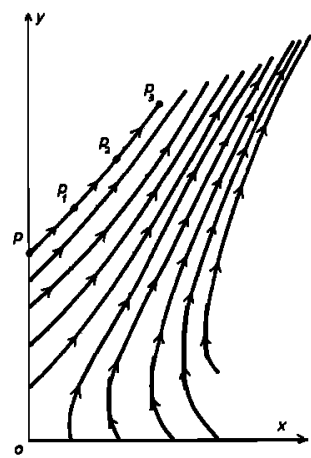

E.Particle movement paths

Fig. 3. Progressive deformation of an element by the superposition of successive displacement increments.

large finite strain is quite complex, depending upon the nature of the displacement increments and therefore upon the values and orientations of the two principal strain rates and the vorticity of the system. The vorticity is perhaps one of the most critical aspects of the geometry relating to effectiveness by which large strains grow with time. We will now examine the nature of the finite strains which can be developed from a variety of types of steady state flow.

\section{Finite STRAIN ARISING From STEADY STATE Flow}

Figures 4 and 5 illustrate some of the types of strain sequences that can arise from steady state flow. The basic incremental strain was considered as an incremental plane distortion without dilation $\left(\dot{e}_{1}=-\dot{e}_{2}, \theta=0\right)$ followed by an incremental rotation (governed by the vorticity $\dot{\omega}$ ). Successive matrix products were computed for different proportions of distortion and vorticity. The value of the principal incremental strain $e_{1 i}$ used in these calculations was 0.1 , and the incremental rotation $\omega_{i}$ varied from zero (pure shear, with coaxial increments) through $\omega_{1}=5.455^{\circ}$ (simple shear) to values of $\omega_{l}=20^{\circ}$. The graphs shown in Figure 4 show how the finite strain values (strain ellipse axes of length $1+e_{1}$, and $1 /(1+$ $\left.e_{1}\right)$ ) vary with their orientation $\theta$, and Figure 5 illustrates successions of strain ellipses arising with different values of incremental rotation, plotted for every two increments.

With pure shear (Figure 5d), because the increments are superposed coaxially (the incremental rotation being zero), the finite strains grow in the most rapid way possible, and high finite strains are produced after only a few increments. The ellipticity of the finite strain ellipse is a power series of the incremental distortion:

$$
1+e_{1}=\left(1+e_{1}\right)^{n}
$$

Ellipticity

$$
\frac{1+e_{1}}{1+e_{2}}=\left(1+e_{12}\right)^{2 n}
$$

where $n$ is the number of increments.

With simple shear (Figure $5 c$ ) the ellipticity of the finite strain ellipse also increases in a nonlinear manner but not at such a rapid rate as was the case with pure shear. The principal axes of successive finite strains rotate in the direction of the incremental rotation, but the rate of rotation of the finite ellipse axes progressively decreases, and the ellipse gradually approaches an asymptote oriented at $45^{\circ}$ to the axes of the first incremental strain ellipse (see Figures 4 and 5c).

A whole spectrum of possibilities of strain sequences lies beiween simple shear and pure shear (e.g., see Figure 4, curves with incremental rotation lying between 0.0 and 5.455). These strain paths accumulate total finite strains with an efficiency between those of pure shear and simple shear. They also have an interesting characteristic that for each value of incremental rotation the axes of the finite strain ellipse approach asymptotically an orientation which lies between the one for pure and simple shear.

Where the incremental rotation exceeds that for simple shear, several other important new characteristics appear in the finite strain sequences (Figures $5 a$ and $5 b$ and Figure 4, curves where $\omega_{i}>5.455$ ). Each strain path begins with an increase in finite strain with successive increments. Howev$\mathrm{er}$, at some particular stage in the sequence the rate of growth of the finite strain declines, eventually to zero, and the finite strain ellipse reaches a maximum value of ellipticity. The value of this maximum finite strain is a function of the value of the incremental rotation component; rotations equal to that for simple shear are infinite, and the maximum finite strain decreases as the incremental rotation increases (see curves in Figure 4). With increasing deformation, the finite strain ellipse axes are no longer constrained to an asymptotic position like those of simple shear. They continue to rotate through the position at $45^{\circ}$ to the initial increment, and as this rotation continues, the finite strain decreases. With increasing increments the finite strain ellipse axes eventually align themselves perpendicular to those of the initial increment, and when they reach this position, the finite strain becomes completely removed. The strain ellipse passes through a circular condition, and the sequence begins once more as it did with the initial undeformed circular marker. The number of increments required to complete a deformation-undeformation cycle depends upon the value of the incremental rotation (see Figures $5 a$ and $5 b$ ), the highest incremental rotations give rise to the most rapid turnover cycles (and also gives those systems with the lowest maximum finite strain ellipticities). The possibility of producing finite strain pulsations was first appreciated by Ramberg 


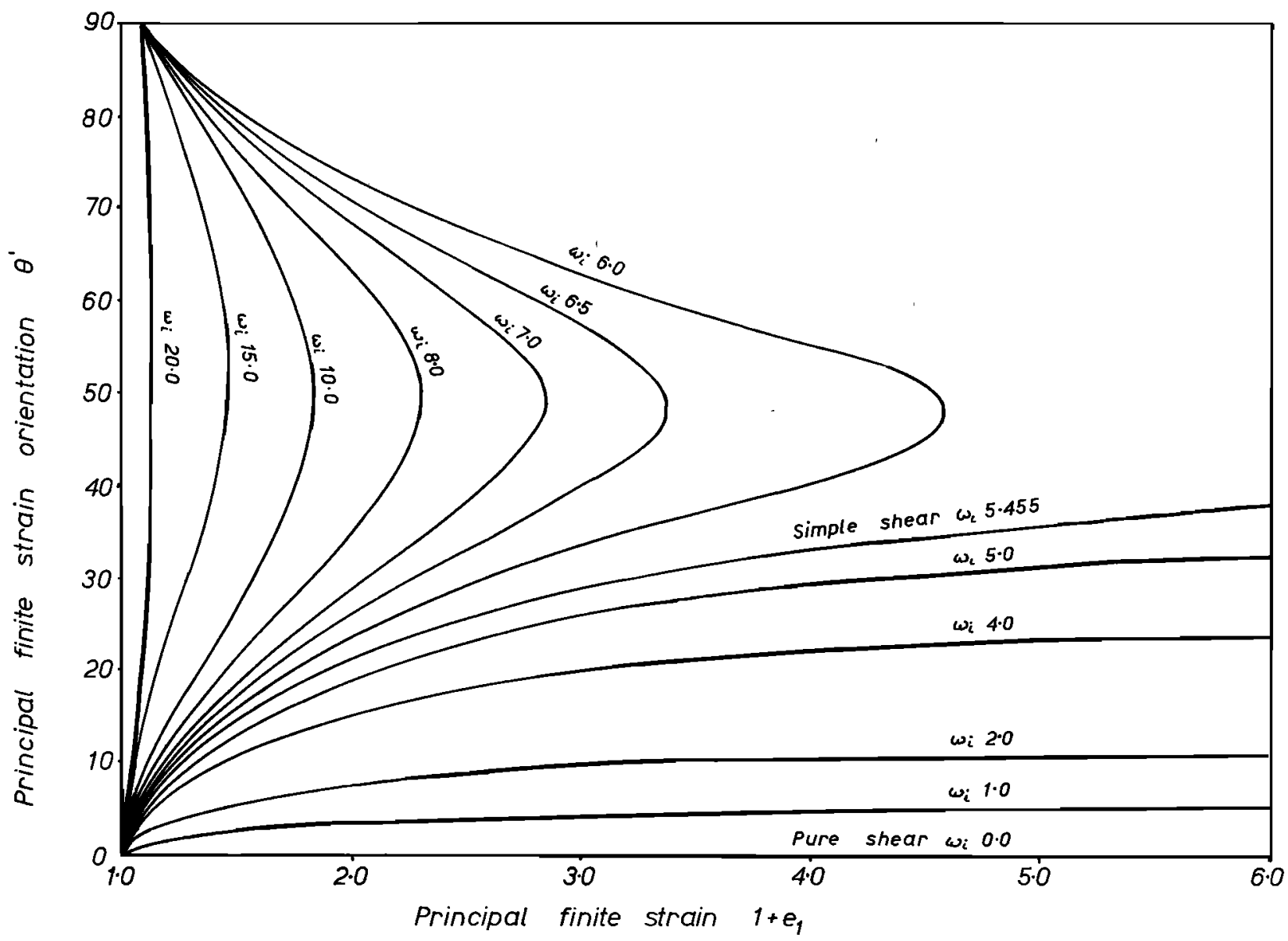

Fig. 4. Curves for finite strain and finite rotation derived by superposing successively increments of distortion $\left(e_{1 i}=0.1\right)$ and rotation $\omega_{i}$.

\section{0

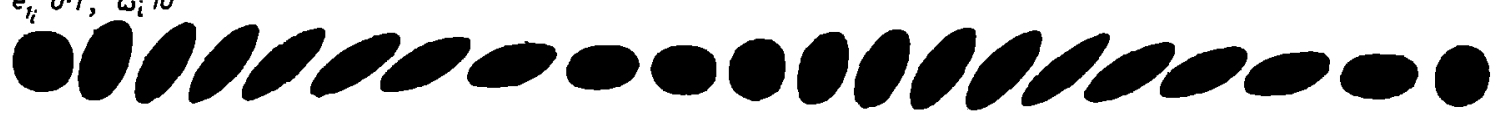

B. $e_{1} 0.1, \omega_{1} 6.5^{\circ}$
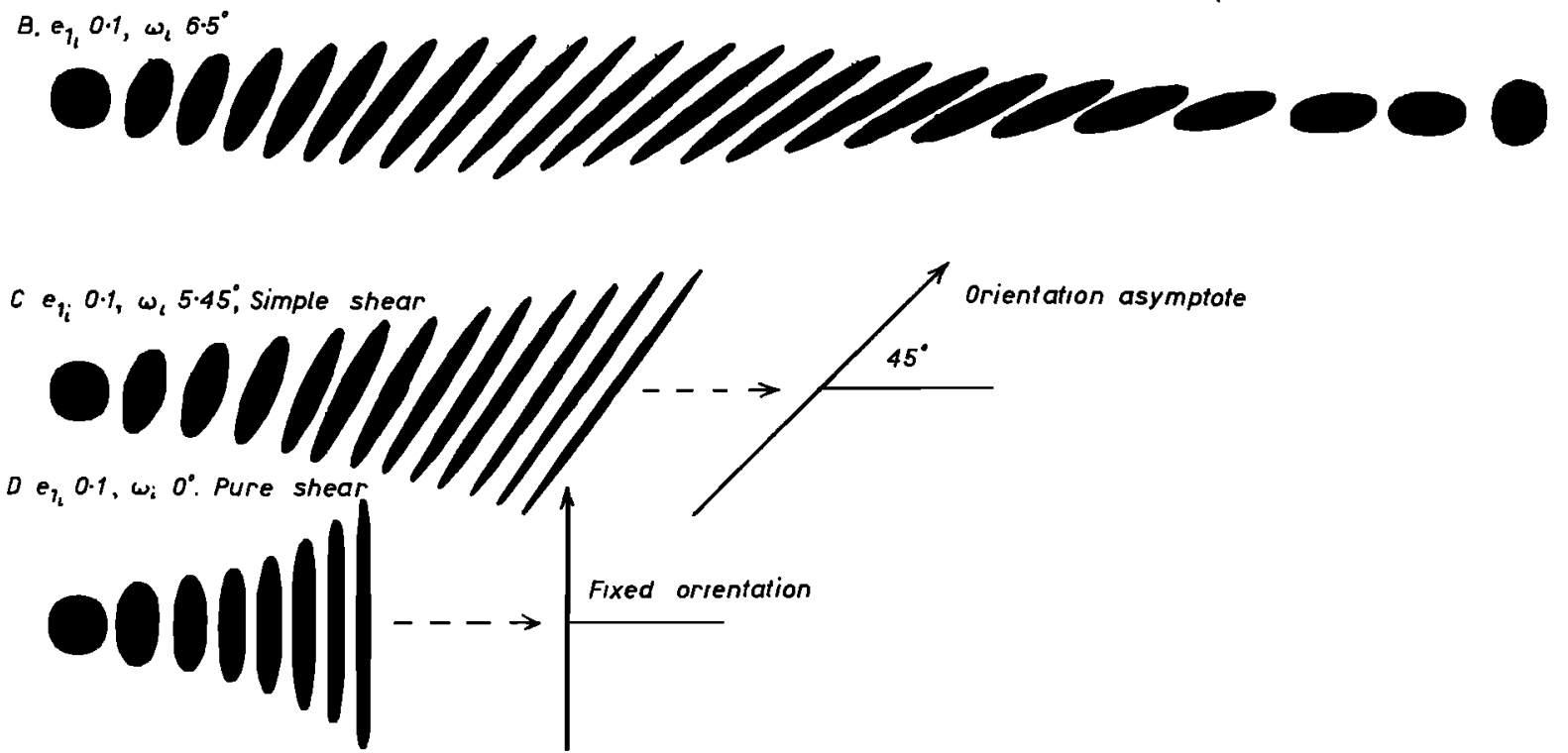

Fig. 5. Diagrammatic representation of the successions of finite ellipses in four of the parts illustrated graphically in Figure 4. 
$[1975 a, b]$ when he investigated the types of flow systems produced by successively superposing alternating increments of pure and simple shear.

It should be clear from this general discussion that steady state flow processes with constant distortional strain rate can produce an enormous range of possible finite strain states depending on the vorticity of the system. For a given time of deformation the largest strains occur in irrotational pure shear. Progressively increasing, but smaller strains occur with finite rotation in simple shear, and where vorticities exceed those for simple shear, periodic deformation and removal of deformation take place with large finite rotations.

It can be seen from this analysis of the complete spectrum of possibilities that arise from steady state flow that if the rotations and vorticities are unconstrained, there is no simple rule relating finite strain to distortional strain rate (Figure 6).

\section{Limitations on Flow In Geological Systems}

We have discussed the geometrical effect of flow in some detail because now we wish to justify our choice of particular types of flow processes as end members limiting realistic types of geological deformation.

The first end-member is that type of steady state flow which leads to maximum finite strain from a given incremental or steady state flow process. There is no difficulty in selecting progressive pure shear as the most rapid of the finite strain growth processes (Figure $5 d$ ).

The end-member defining the minimum effectiveness of building large finite strain with a given flow process requires more detailed discussion. The general analysis of steady state flow has shown that certain processes lead to finite strains periodically increasing and decreasing in a pulsating way. How common is this effect in tectonic processes? Ramberg's [1975b, pp. 32-34] discussion of this point shows that rock flow of this type in nappe sheets and in fold formation is unlikely to be common, or if it does occur, it is likely to be for only short periods during the deformation history. He pointed out that the rotation of less ductile inclusions such as crystal porphyroblast or pebbles in a more ductile matrix could produce such a pulsatory strain effect in the inclusions. Such a process only occurs on a very local scale, and we cannot think of any tectonic process likely to have significance on a regional scale which
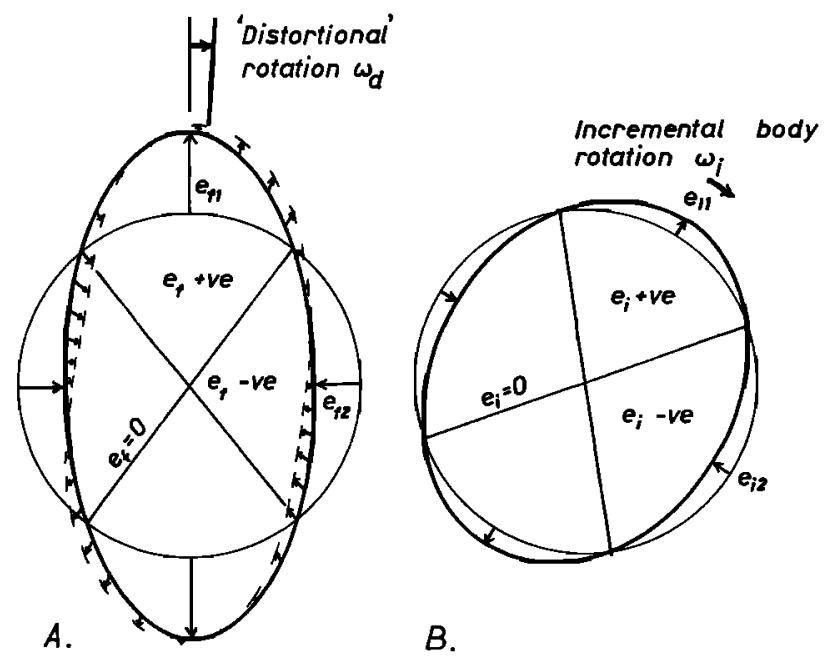

Fig. 6. General effects of superimposing an incremental strain B on already established finite strain state $\mathbf{A}$.

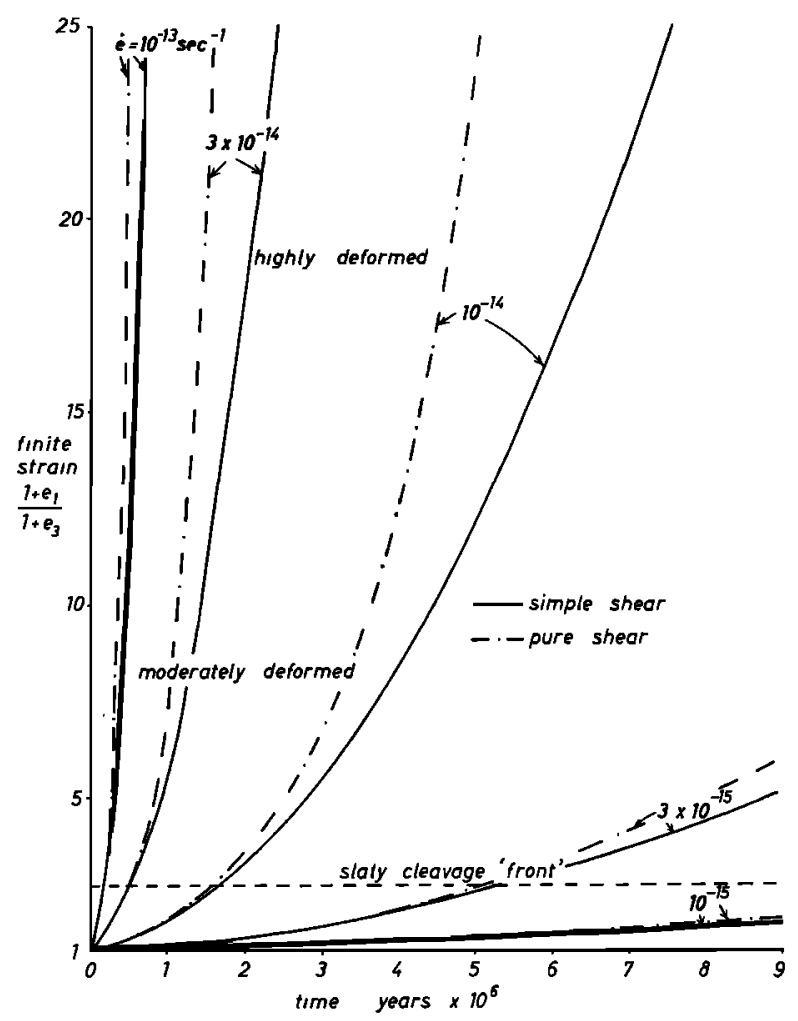

Fig. 7. Computations of finite strain state arising by processes of pure shear and simple shear with steady state flow of differing rates over a particular time interval.

could build pulsatory finite strains in this way. The steady state process which forms the boundary to such pulsatory processes is simple shear (Figure 5c). The principal strain rate axes during steady state flow by simple shear are oriented at $45^{\circ}$ to the shear displacement direction of the shear, whereas the finite strain axes come to lie closer to the shear direction. During the flow process shown in this figure the distortional effects of the increment move the established finite strain axis anticlockwise, but the incremental rotation or vorticity always move it clockwise at a rate just slightly greater than that of the anticlockwise rotation. With large shears and large finite strains, the two effects are almost identical in their positive and negative rotational effects: the principal extension axis of the finite strain comes to lie closer and closer to the shear direction but never passes through it. This means that the finite strain can never acquire increments which lead to a decrease of its previously established total strain state. Because simple shear is the limiting case of effectiveness of the vorticity to pass into the 'pulsating' strain field and because we do not believe that this field has regional geological significance, we think it justified to take simple shear as the lower most bound of any steady state processes which lead to large strain states in tectonic processes.

\section{Finite Strain States AND TIME IN Tectonic Processes}

There is now available a very large bank of data giving measured finite strains from many different types of naturally deformed rock in many differing environments, and a summary is set out in Appendix A, Figure Al, and Table 1. These data have been acquired from the measurement of a whole 
variety of strain markers, thus yielding different types of strain parameters. To facilitate comparison, the data have been referred to one of the following parameters: longitudinal strain $(1+e)$, shear strain $(\gamma)$, or axial ratio $(R)$ of the strain ellipse. A review of this information shows the following minimum and maximum finite strains:

Longitudinal strains from

$$
1+e_{1}=1 \text { to } 3 \quad 1+e_{3}=1 \text { to } 0.13
$$

Shear strains from

$$
\gamma=0 \text { to } 42.55
$$

Axial ratios from

$$
R=1 \text { to } 13.5
$$

(Table 1) and

$$
R=1 \text { to } 25
$$

Some of the data in Figure Al and Table 1 represent regionally penetrative deformations probably occurring through rock masses of one or more cubic kilometers in volume. In many instances, possible ductility contrasts (e.g., between fossils and matrix) means that the strain quoted is a minimum value, and in others, significant volume reductions may be present. High strains of $\gamma$ up to 40 (equivalent to 'axial ratios' of 1600 ) do occur and can occasionally be measured, but they seem to be typically localized in narrow planar zones, having a special evolutionary history (thrust and shear zones, mylonite belts).

The duration of time necessary to develop these finite strains is very difficult to assess. Precise stratigraphical control for upper and lower time brackets for individual 'phases of deformation' are difficult to obtain, and the errors involved may be critical for the arguments presented here; moreover, they always give maximum intervals and deformation throughout these intervals was not necessarily continuous. Detailed structural analyses of fold-and-thrust and imbricate thrust terrains often indicate that such time periods may be subdivided into sequences of subphases any one of which could produce the finite strain in a comparatively short time period [e.g., Dahlstrom, 1970; Pfiffner, 1978].

In Figure B1, some data on orogenic movements are listed. The time interval for penetrative deformation (e.g., indicated by folding) typically range from 1 to $30 \mathrm{~m}$.y., with a maximum of the data investigated lying between 1 and $5 \mathrm{~m} . \mathrm{y}$. But it is possible the finite strains may have been developed over a much shorter time interval, perhaps of the order of 100,000 years.

\section{Strain Rates and Finite Strain Calculations}

We now wish to show how the pure and simple shear models for progressive deformation can be used to predict the finite strains arising by steady state constant strain rate flow.

The most effective way of building up a large finite strain from strain increments in plane strain is that of progressive pure shear. Clearly, this is a highly specialized incremental process, but finite strains might arise in this way from geological processes. It can easily be shown that the general case of heterogeneous finite strain leads to general states of rotational strain [Ramsay and Graham, 1970], and clearly such rotational finite strains cannot have been produced by a progressive irrotational process. However, at a few singular points in a het- erogeneously strained body it may be possible to have finite strains close to pure shear. For example, the strains built up along the inner arc of a buckled competent layer approximate to pure shear, especially at the fold hinge zones.

The build up of finite strain by progressive pure shear with no volume dilation gives the following values for finite strain

$$
\begin{gathered}
1+e_{1 j}=\left(1+\dot{e}_{i}\right)^{n} \\
1+e_{2 f}=1 \\
1+e_{3 j}=\left(1+\dot{e}_{1}\right)^{-n}
\end{gathered}
$$

where $1+e_{1}$, etc. refer to the lengths of the axes of the finite strain ellipsoid, and $n$ the number of increments of the deformation. The actual calculation of the curves in Figure 7 is speeded up by using

$$
\lim _{y \rightarrow \infty}\left(1+\frac{1}{y}\right)^{y}=2.718
$$

(the exponential constant $e$ ). This limit rewritten in terms of the above equations

$$
\lim _{\substack{i \rightarrow 0 \\ n \rightarrow \infty}}(1+e)^{n}=2.718
$$

Figure 7 shows strains arising over periods of several million years from different principal strain rates.

What is very striking here (Figure 7) is, first, the markedly nonlinear accumulation of finite strain with time and, second, how a comparatively small variation in strain rate leads to great differences in the finite strain accumulation in a specific period of time. If, for example, the deformation were continuous and took place over a period of $5 \mathrm{~m}$.y., strain rates of $3 \times 10^{-14} \mathrm{~s}^{-1}$ would produce very high finite strains, whereas strain rates of $10^{-15} \mathrm{~s}^{-1}$ would produce strains below the slaty cleavage front.

Pure shear gives rise to the most rapid growth of finite strain. We now investigate the effects of a similar range of strain rates but with the incremental process being that of simple shear, a process which we have shown to possibly mark the geologically least effective method of building finite strains. The various strain rates for pure shear have been transformed to shear displacement rates using $\dot{\gamma}=2 \dot{e}$, integrated over time periods from 0 to $10 \mathrm{~m} . \mathrm{y}$. and the finite shear strains $\gamma_{\text {, transformed back into values for finite strains }}$

$$
\frac{1+e_{1 f}}{1+e_{2 f}}=\frac{1}{2}\left(n^{2} \dot{\gamma}^{2}+2+n \dot{\gamma}\left(n^{2} \dot{\gamma}^{2}+4\right)^{1 / 2}\right)
$$

The curves illustrating strain accumulation with time (Figure 7) show broadly similar features to those for pure shear. For a given total deformation time, the finite strain for a given strain rate is less than that for pure shear.

As these two sets of calculations represent certain upper and probable lower bounds of effectiveness of accumulation of strain, we arrive at a most interesting conclusion: to satisfy geologically values of moderate finite strains built up by steady state flow over time periods of less than $5 \mathrm{~m}$.y., our strain rates have to be constrained between the limits $10^{-13} \mathrm{~s}^{-1}$ and $10^{-15} \mathrm{~s}^{-1}$. Strains faster than $10^{-13} \mathrm{~s}^{-1}$ produce very high strains (realized, e.g., in mylonite zones; see Schmid [1975] and Pfiffner [1977] for the Lochseiten calc mylonite) or necessitate deformation to take place in a time of much less than $1 \mathrm{~m} . \mathrm{y}$., whereas strain rates slower than $10^{-15} \mathrm{~s}^{-1}$ lead to very small strains. 
TABLE 1. Strain Data Compilation

\begin{tabular}{|c|c|c|c|c|c|}
\hline Source & Location & Rock Type & $\begin{array}{c}\text { Strain } \\
\text { Marker }\end{array}$ & $\begin{array}{l}\text { Stretching } \\
1+e\end{array}$ & $\begin{array}{c}\text { Shortening } \\
1-e\end{array}$ \\
\hline Badoux [1963] & Alps/Helvetics & calcschistes & belemnites & $1-3$ & \\
\hline Badoux [1965] & Alps/Helvetics & limestone & belemnites & $1.05-2.15$ & \\
\hline Badoux [1970] & Alps/Helvetics & limestone & oöids & $1.2-1.7$ & $0.6-0.13$ \\
\hline $\begin{array}{l}\text { Borradaile and Johnson } \\
\text { [1973] }\end{array}$ & Caledonides/Scotland & sandstone, siltstone & dykelets & $1.25-2.57$ & $0.67-0.34$ \\
\hline Breddin [1956a] & Rheinisches Schiefergebirge & $\begin{array}{l}\text { limestone, sandstone, } \\
\text { slate, marl }\end{array}$ & fossils & $1.02-1.33$ & $0.87-0.51$ \\
\hline Breddin $[1956 b]$ & Rheinisches Schiefergebirge & shale & fossils & $1.05-1.1$ & $0.8-0.7$ \\
\hline Breddin [1957] & Rheinisches Schiefergebirge & $\begin{array}{l}\text { sandstone, slate, } \\
\text { graywacke }\end{array}$ & fossils & $1.14-1.34$ & $0.45-0.17$ \\
\hline Breddin $[1958 a]$ & Rheinisches Schiefergebirge & shale & fossils & $1.0-1.1$ & $0.9-0.73$ \\
\hline Breddin $[1958 b]$ & Rheinisches Schiefergebirge & slate & fossils & 1.09 & $0.9-0.75$ \\
\hline Breddin [1964] & Rheinisches Schiefergebirge & marl & fossils & & $0.82-0.67$ \\
\hline $\begin{array}{l}\text { Chapple and Spang } \\
\text { [1974] }\end{array}$ & Appalachians & limestone & calcite twins & $1.002-1.086$ & $0.994-0.922$ \\
\hline Dèbat [1974] & $\begin{array}{l}\text { Variscides/Montagne } \\
\text { Noire }\end{array}$ & gneiss & $\begin{array}{l}\text { feldspar } \\
\text { crystals }\end{array}$ & $1.03-2.37$ & $0.34-0.23$ \\
\hline Furtak [1965] & Rheinisches Schiefergebirge & slate, sandstone & $\begin{array}{l}\text { fossils, minor } \\
\text { folds }\end{array}$ & $1.13-1.28$ & $0.75-0.65$ \\
\hline Gairola [1976] & Lesser Himalaya & shale, limestone & nummulites & & 0.8 \\
\hline Groshong [1975] & Appalachians & limestone & calcite twins & $1.0028-1.0419$ & $0.9993-0.9433$ \\
\hline Langheinrich [1967a] & Rheinisches Schiefergebirge & sandstone & brachiopods & 1.12 & 0.8 \\
\hline Langheinrich $[1967 b]$ & Alps/N Calcareous Alps & marl & ammonites & & $0.96-0.7$ \\
\hline Mukhopadhyay et al. [1969] & India & schist, phyllite & microfolds & & $0.23-0.15$ \\
\hline Nickelsen [1966] & Appalachians & silt, shale & fossils & & $0.93-0.9$ \\
\hline Plessmann [1965] & Rheinisches Schiefergebirge & slate, graywacke & worm tubes & & $0.9-0.6$ \\
\hline Source & Location & Rock Type & $\begin{array}{l}\text { Strain } \\
\text { Marker }\end{array}$ & & $\begin{array}{l}\text { Axial Ratio of } \\
\text { Strain Ellipse }\end{array}$ \\
\hline $\begin{array}{l}\text { Albrecht and Furtak } \\
\text { [1965] }\end{array}$ & Alps/Subalpine Molasse & $\begin{array}{l}\text { marl, marly limestone } \\
\text { sandstone }\end{array}$ & fossils & & $1.1-1.4$ \\
\hline Audren et al. [1976] & Variscides/Bretagne & conglomerate, schist & \multicolumn{2}{|c|}{ pebbles, quartz grains } & $1.2-6.2$ \\
\hline Bhattacharya [1966] & India & conglomerate & \multirow{4}{*}{\multicolumn{2}{|c|}{$\begin{array}{l}\text { pebbles } \\
\text { oöids } \\
\text { oöids, clasts } \\
\text { clasts }\end{array}$}} & 9.3 \\
\hline Cloos [1971] & Appalachians & limestone & & & $1.07-8.04$ \\
\hline Dunnet [1969] & Sardinia & oölite, grit & & & $1.45-4.5$ \\
\hline $\begin{array}{l}\text { Dunnet and Siddans } \\
\text { [1971] }\end{array}$ & Sardinia & grit, tuff & & & $1.2-4.0$ \\
\hline $\begin{array}{l}\text { Engelder and Engelder } \\
\text { [1977] }\end{array}$ & Appalachians & clastic sediments & \multicolumn{2}{|l|}{ crinoid ossicles } & $1.05-1.23$ \\
\hline $\begin{array}{l}\text { Furtak and Hellermann } \\
\text { [1961] }\end{array}$ & Central Europe & sandstone, siltstone & \multicolumn{2}{|l|}{ fossil plants } & $1-1.5$ \\
\hline $\begin{array}{l}\text { Le Corre and Le Theoff } \\
\text { [1976] }\end{array}$ & Variscides/Bretagne & conglomerate, slate & \multicolumn{2}{|l|}{$\begin{array}{l}\text { pebbles, quartz } \\
\text { grains }\end{array}$} & $1.3-6$ \\
\hline Le Théoff [1977] & Variscides/Bretagne & conglomerate & \multirow{2}{*}{\multicolumn{2}{|c|}{$\begin{array}{l}\text { pebbles } \\
\text { pebbles }\end{array}$}} & $1.5-6.5$ \\
\hline $\begin{array}{l}\text { Mukhopadhyay and } \\
\text { Bhattacharya [1969] }\end{array}$ & India & conglomerate & & & 1.87 \\
\hline Pfiffner [1977] & Alps/Helvetics & conglomerate, volcanics & \multirow{3}{*}{\multicolumn{2}{|c|}{$\begin{array}{l}\text { pebbles, vesicles } \\
\text { nodules } \\
\text { oöids, ammonites }\end{array}$}} & $1.3-13.5$ \\
\hline Roberts [1973] & Caledonides/Eire (Donegal) & slate, grit & & & $1.5-3.0$ \\
\hline $\operatorname{Tan}[1973]$ & Alps/Helvetics & limestone & & & $1.8-2.3$ \\
\hline Wickham [1973] & Appalachians & limestone & \multicolumn{2}{|l|}{ fibers } & $1.3-2.0$ \\
\hline Source & Location & Rock Type & \multicolumn{2}{|l|}{$\begin{array}{c}\text { Strain } \\
\text { Marker }\end{array}$} & $\begin{array}{l}\text { Shear } \\
\text { Strain }\end{array}$ \\
\hline $\begin{array}{l}\text { Burg and Laurent } \\
\text { [1978] }\end{array}$ & Massif Central/France & granodiorite & \multicolumn{2}{|l|}{ planes, xenoliths } & $0-3.64$ \\
\hline Escher et al. [1975] & Archean basement/Greenland & gneiss & \multirow{3}{*}{\multicolumn{2}{|c|}{$\begin{array}{l}\text { dykes } \\
\text { pipes } \\
\text { bedding planes }\end{array}$}} & $2.6-9.4$ \\
\hline McLeish [1971] & Caledonides/Scotland & pipe rock & & & $0.76-42.55$ \\
\hline $\begin{array}{l}\text { O. A. Pfiffner (unpublished } \\
\text { manuscript 1979) }\end{array}$ & Alps/Helvetics & limestone & & & $35-40$ \\
\hline $\begin{array}{l}\text { Ramsay and Graham } \\
{[1970]}\end{array}$ & Caledonides/Scotland & metagabbro & \multicolumn{2}{|l|}{ planes } & $0-22$ \\
\hline
\end{tabular}

Because quite small differences in strain rate lead to dramatic variations in finite strain, we are able to develop another interesting conclusion about variations in strain rate: it is well known that when layers of differing properties become folded together they take up differing amounts of finite strain.
These strain variations lead to changes in the orientation of planar deformation fabrics related to the $X Y$ plane of the strain ellipsoid and give rise to the phenomenon of cleavage refraction [Sorby, 1853; Harker, 1885; Furtak, 1962]. These strain variations may be quite marked; for example, principal 
finite strain ratios $\left(1+e_{1}\right) /\left(1+e_{3}\right)$ typically seen in the limbs of many folded limestone-shale or sandstone-shale multilayers are generally in the range competent layer $2: 1$ to incompetent layers $6: 1$. From the calculations we have made above it can be deduced that these variations in finite strains can be accomplished with differences in strain rate of less than one order of magnitude $\left(1.1 \times 10^{-14} \mathrm{~s}^{-1}\right.$; cf. $3.2 \times 10^{-14} \mathrm{~s}^{-1}$ if these strains accumulated over a period of $1 \mathrm{~m}$.y. by a simple shear mechanism).

\section{Conclusions}

1. Many rocks in orogenic zones showing features like cleavage occupy a somewhat limited deformation field, typical values for axial ratios ranging between 1 and 10 .

2. In relatively young orogenic zones where we have good control of the deformation, it appears that in many cases these measurable finite strains took less than $10 \mathrm{~m}$.y. and maybe as little as 100,000 years to form.

3. To produce such strains over these time spans, one arrives at (conventional) strain rates between $10^{-13} \mathrm{~s}^{-1}$ and $10^{-15}$ $\mathrm{s}^{-1}$. Slower and faster strain rates have to be expected in apparently 'undeformed' rocks and in mylonite zones, respectively.

4. The observed differences in finite strains between competent and incompetent layers (e.g., quartzite and shale) can be accounted for by differences in strain rate of less than one order of magnitude (e.g., $10^{-14} \mathrm{~s}^{-1}$ versus $3 \times 10^{-14} \mathrm{~s}^{-1}$ ).

\section{APPENDIX A: BIBLIOGRAPHY FOR FIGURE Al}

Barr, M. W. C., Crustal shortening in the Zambezi belt, Philos. Trans. R. Soc. London Ser. A, 280, 555-567, 1976.

Beutner, E. C., Slaty cleavage and related strain in Martinsburg slate Delaware Water Gap, New Jersey, Am. J. Sci., 278, 1-23, 1978.

Borradaile, G. J., Bulk finite tectonic strain estimates from the deformation of Neptunian dykes, Tectonophysics, 22, 127139, 1974.

Borradaile, G. J., A study of a granite-gneiss transition and accompanying schistosity formation, SE Spain, J. Geol. Soc. London, 132, 417-428, 1976.

Borradaile, G. J., On cleavage and strain: Results of a study in West Germany using tectonically deformed sand dykes, $J$. Geol. Soc. London, 133, 146-164, 1977.

Cucchi, R. J., Petrofabrico del conglomerado de la formacion La Lola, Sierras Australes de la Provincia de Buenos Aires, Rev. Assoc. Geol. Argent., 21, 71-106, 1966.

Elliott, D., Determination of finite strain and initial shape from deformed elliptical objects, Geol. Soc. Am. Bull., 8I, 2221-2236, 1970.

Flinn, D., On the deformation of the Funzie conglomerates, Fetlar, Shetland, J. Geol., 64, 480-505, 1956.

Gay, N. C., The analysis of strain in the Barberton Mountain Land, Eastern Transvaal, using deformed pebbles, $J$. Geol., 77, 377-396, 1969.

Gay, N. C., and R. E. P. Fripp, The control of ductility on the deformation of pebbles and conglomerates, Philos. Trans. R. Soc. London Ser. A, 283, 109-128, 1976.

Graham, R. H., Quantitative deformation studies in the Permian rocks of Alpes Maritimes, in 'Goguel' Symposium, pp.
219-238, Bureau de Recherches Geologiques et Minieres, Orleans, France, 1978.

Hasan, Z. U., and S. N. Sarkar, The deformation of Dharhara conglomerate in Monghyr district, India, Nor. Geol. Tidsskr., 47, 159-170, 1967.

Helm, D. G., and A. W. B. Siddans, Deformation of a slaty, lapillar tuff in the English Lake District: Discussion, Geol. Soc. Am. Bull., 82, 523-531, 1971.

Hossack, J. R., Pebble deformation and thrusting in the Bygdin area (Southern Norway), Tectonophysics, 5, 315$339,1968$.

LeBlanc, D., Etude géologique dans le Rif externe oriental au nord de Taza (Maroc), thèse d'etat, 293 pp., Univ. Toulouse, Toulouse, France, 1975.

Le Théoff, B., Marquers ellipsoidaux et déformation finie; application aux synclinaus de Bretagne centrale et aux 'mantled gneiss dômes' de Kuopio (Finlande), thèse, 96 pp., Univ. de Rennes, Rennes, France, 1977.

Lisle, R. J., Clastic grain shape and orientation in relation to cleavage from the Aberystwyth Grits, Wales, Tectonophysics, 39, 381-395, 1977.

Mendum, J. R., A strain study of the Strathan conglomerates, N. Sutherland, Scott. J. Geol. 12(2), 135-146, 1976.

Mimran, Y., Strain determination using a density-distribution technique and its application to deformed Upper Cretaceous Dorest chalks, Tectonophysics, 31, 175-192, 1976.

Mitra, S., A quantitative study of deformation mechanisms and finite strain in quartzites, Contrib. Mineral. Petrol., 59, 203-226, 1976.

Mitra, S., Microscopic deformation mechanisms and flow laws in quartzites within the South Mountain Anticline, $J$. Geol., 86, 129-152, 1978.

Mukhopadhyay, D., Strain measurements from deformed quartz grains in the slaty rocks from the Ardennes and Eiffel, Tectonophysics, 16, 279-296, 1973.

Oele, J. A., The structural history of the Vall Ferrera area, the transition zone between the Aston massif and the SalatPallaresa anticlinorium (Central Pyrenees, France, Spain), Leidse Geol. Meded., 38, 129-164, 1966.

Paulis, R. V., A method of strain measurement using initially orthogonal planar and linear markers, Tectonophysics, 34, 29-36, 1976.

Pfiffner, O. A., Strain analysis in folds (Infrahelvetic complex, Central Alps), Tectonophysics, 57, 1979.

Pfiffner, O. A., Strain analysis in slates of the Verrucano and Quartenschiefer formations in the Helvetic nappes (eastern Switzerland), unpublished manuscript, 1979.

Roberts, B., and A. W. B. Siddans, Fabric studies in the Llwyd Mawr ignimbrite, Caernavonshire, North Wales, Tectonophysics, 12, 283-306, 1971.

Siddans, A. W. B., Analysis of three-dimensional, homogeneous finite strain using ellipsoidal objects, Tectonophysics, 64, 1-16, 1980.

Stauffer, M. R., Tectonic strain in some volcanic, sedimentary, and intrusive rocks near Canberra, Australia: A comparative study of deformation fabrics, N.Z. J. Geol. Geophys., 10, 1079-1108, 1967.

Subieita, T. A., Analyse quantitative de la déformation dans un sécteur de la zone externe des Alpes (La Javie- NE de Digne), thèse, 93 pp., Univ. Montpellier, Montpellier, France, 1977.

Talbot, C. J., The minimum strain ellipsoid using deformed 


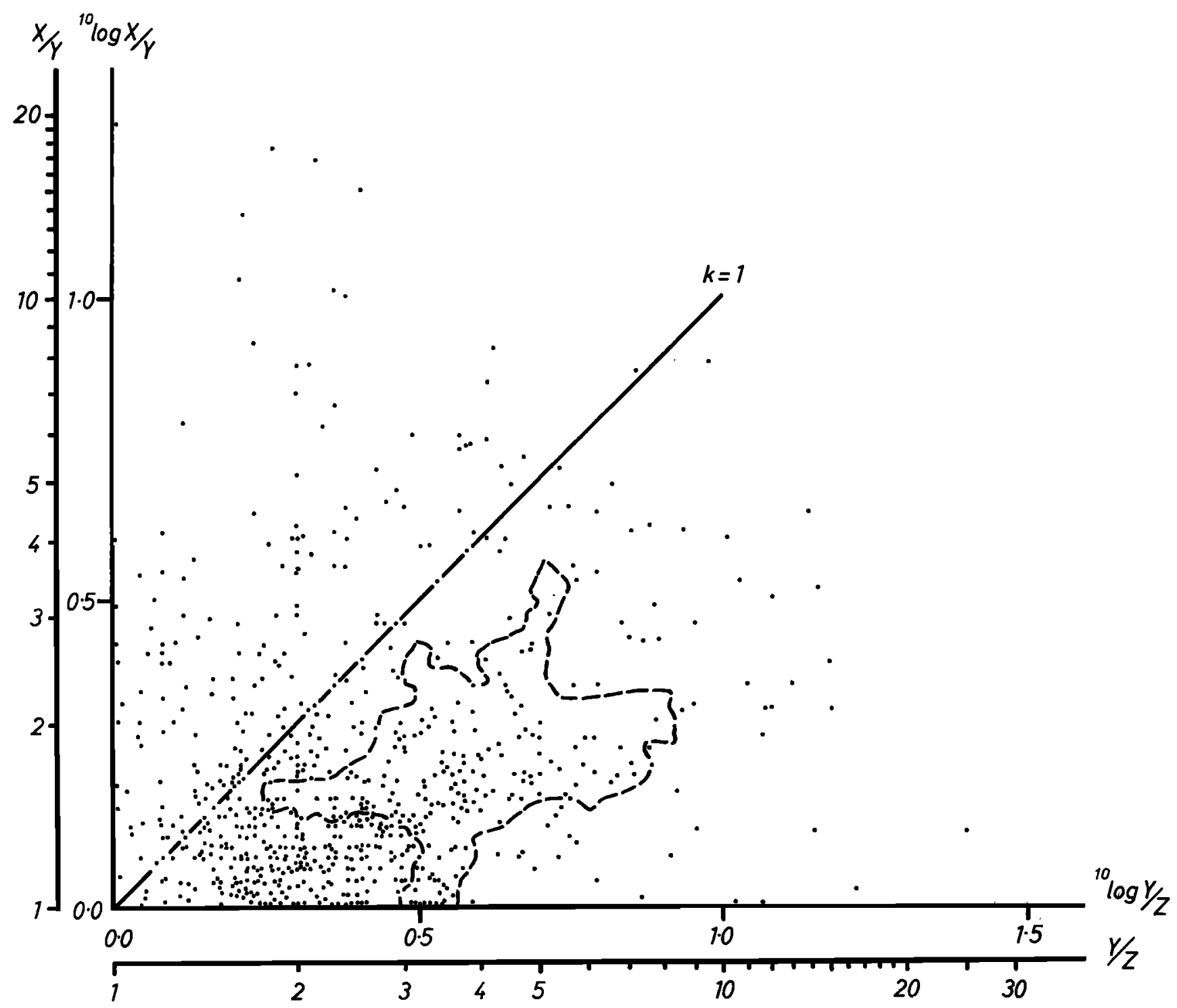

Fig. A1. Graphical representation of three-dimensional finite strain states based on measurements of naturally deformed objects. The ratio $X / Y$ represents the measured principal plane ellipticity $\left(1+e_{1}\right) /\left(1+e_{2}\right)$ and $Y / Z$ the ellipticity $\left(1+e_{2}\right) /\left(1+e_{3}\right)$. Data from Appendix A. The field inside the dashed line represents the strains from some 990 slates [Ramsay and Wood, 1973].

quartz veins, Tectonophysics, 9, 47-76, 1970.

Tan, B. K., Deformation of particles developed around rigid and deformable nuclei, Tectonophysics, 24, 243-257, 1974.

Tan, B. K., Oolite deformation in Windgällen, Canton Uri, Tectonophysics, 31, 157-174, 1976.

Tavernar-Smith, R., A deformed Katanga conglomerate in northern Rhodesia, Trans. Geol. Soc. S. Afr., 65, 177-192, 1962.

Taylor, C., Tectonic studies of the SW end of the Aar massif, Switzerland, thesis, 187 pp., Univ. of Luton, Luton, England, 1976.

Thakur, V. C., Computation of the values of the finite strains in the Molare region, Ticino, Switzerland, using stretched tourmaline crystals, Geol. Mag., 109, 445-450, 1972.

Tobish, O. T., R. S. Fiske, S. Sacks, and D. Taniguchi, Strain in metamorphosed volcaniclastic rocks and its bearing on the evolution of orogenic belts, Geol. Soc. Am. Bull., 88, 23-40, 1977.

Wood, D. S., Current views of the development of slaty cleavage, Annu. Rev. Earth Planet. Sci., 2, 369-401, 1974.

Wood, D. S., G. Oertel, J. Singh, and H. F. Bennet, Strain and anisotropy in rocks, Philos. Trans. R. Soc. London Ser. A, 280/283, 27-42, 1976.

Zagorchev, I. S., T. V. Tsankov, and K. M. Sapundviev, Strain variation in a part of the Skrino anticline, district of Kjustendil, determined from deformed reduction spots, Dokl. Bolg. Akad. Nauk, 29, 1333-1336, 1976. 


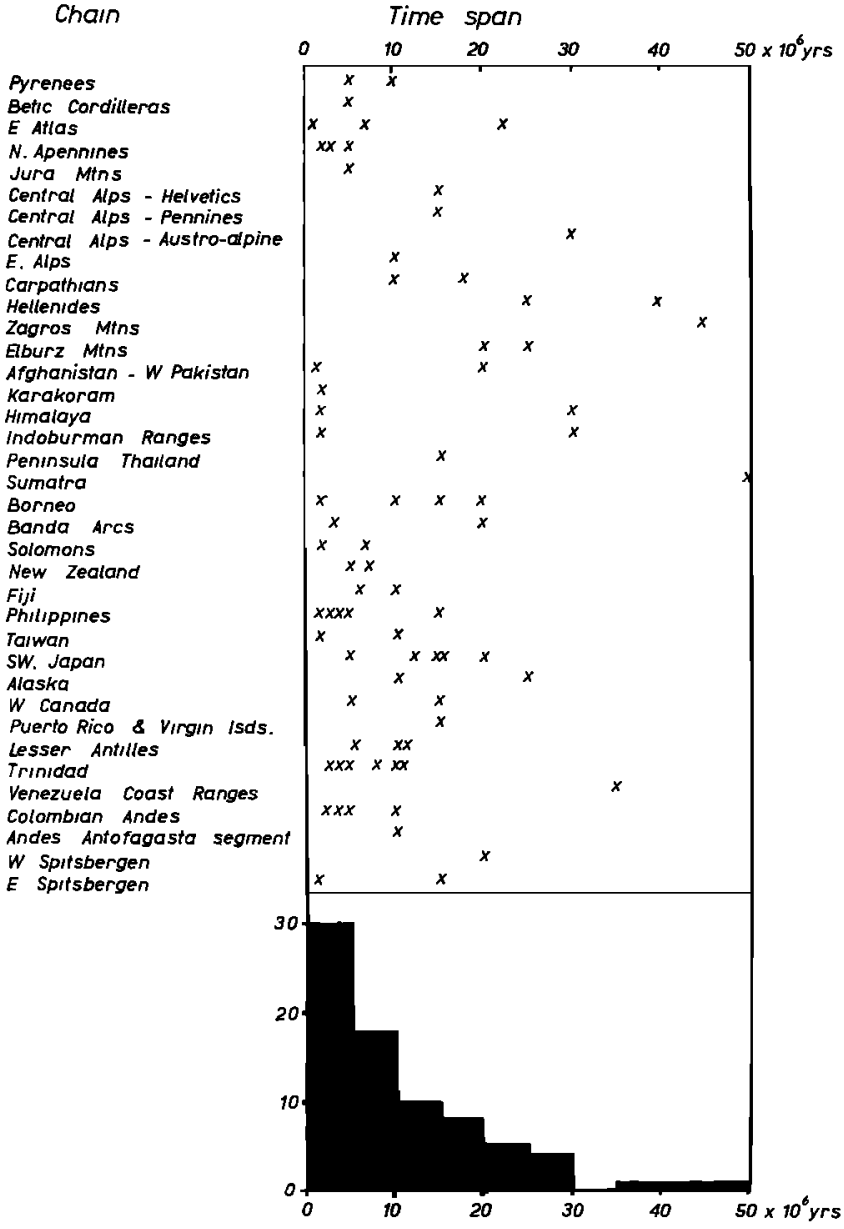

Fig. B1. Time span of deformation phases in orogenic chains. References from Appendix B.

\section{APPENDIX B: BIBLIOGRAPHY FOR FIGURE B1}

Milnes, A. G., and O. A. Pfiffner, Structural development of the infrahelvetic complex, eastern Switzerland, Eclog. Geol. Helv., 70, 83-95, 1977.

Spencer, A. M. (Ed.), Mesozoic-Cenozoic orogenic belts, Spec. Publ. Geol. Soc. London, 4, 809 pp., 1974.

Wildi, W., M. Nold, and J. Uttinger, La Dorsale calcaire entre Tétouan et Assifane (Rif interne, Maroc), Eclog. Geol. Helv., 70, 371-415, 1977.

Acknowledgment. We wish to acknowledge with thanks financial support from the Schweizerischer Nationalfonds (grant 2.859-0/77).

\section{REFERENCES}

Albrecht, K., and H. Furtak, Die tektonische Verformung der Fossilien in der Faltenmolasse Oberbayerns zwischen Ammer und Leitzach, Geol. Mitt., 5, 227-248, 1965.

Audren, D., J. P. Brun, P. Cobbold, J. Cogne, M. Inglésias, P. Jegonzo, C. Le Corre, J. Le Metour, B. Le Théofi, and D. Rabu, Données complémentaires sur la géometrie du plissement et sur les variations de forme et d'orientation de l'ellipsoide de deformation dans l'arc hercynien ibéro-armoricain, Bull. Soc. Géol. Fr., 18, 757-762, 1976.

Badoux, H., Les bélemnites tronçonnées de Leytron (Valais), Bull. Soc. Vaudoise Sci. Nat., 68, 1-7, 1963.

Badoux, $H$., Déformation du Lias inférieur de la nappe du Wildhorn à Drône (Valais), Eclog. Geol. Helv., 58, 999-1001, 1965.

Badoux, H., Les oolites déformées du Vélar (massif de Morcles), Eclog. Geol. Helv., 67, 539-548, 1970.
Bhattacharya, D. S., Pebble elongation parallel to the axis of rolling, Tschermaks Mineral. Petrogr. Mitt., 11, 65-71, 1966.

Borradaile, G. J., and H. D. Johnson, Finite strain estimates from the Dalradian dolomitic formation, Islay, Argyllshire, Tectonophysics, 18, 248-259, 1973.

Breddin, H., Die tektonische Deformation der Fossilien im Rheinischen Schiefergebirge, Z. Dtsch. Geol. Ges., 106, 227-305, $1956 a$.

Breddin, H., Tektonische Gesteinsdeformation im Karbongürtel Westdeutschlands und Süd-Limburgs, Z. Dtsch. Geol. Ges., 107, 231-260, $1956 b$.

Breddin, H., Tektonische Fossil- und Gesteinsdeformation im Gebiet von St. Goarshausen (Rheinisches Schiefergebirge), Decheniana, 110, 289-350, 1957.

Breddin, H., Tektonische Gesteinsdeformation im kaum gefalteten Karbon des Eckelenzer Steinkohlerevieres, Neues Jahrb. Geol. Palaeontal. Monatsh., 3/4, 172-188, 1958a.

Breddin, H., Tektonisch deformierte Fossilien in der Zeche Mathias Stinnes in der Emscher-Mulde und ihre Bedeutung für Tektonik und Paläontologie des Ruhrkarbons, Glueckauf, 33/34, 1095-1101, $1958 b$.

Breddin, H., Die tektonische Deformation der Fossilien und Gesteine in der Molasse von St. Gallen (Schweiz), Geol. Mitt., 4, 1-68, 1964.

Burg, J. P., and Ph. Laurent, Strain analysis of a shear zone in a granodiorite, Tectonophysics, 47, 15-42, 1978.

Chapple, W. M., and J. H. Spang, Significance of layer-parallel slip during folding of layered sedimentary rocks, Geol. Soc. Am. Bull., 85, 1523-1534, 1974.

Cloos, E., Microtectonics Along the Western Edge of the Blue Ridge, Maryland and Virginia, 234 pp., The John Hopkins Press, Baltimore, Md., 1971.

Crittenden, M., Viscosity and finite strength of the mantle as determined from water and ice loads, Geophys. J. R. Astron. Soc., 14, 261-279, 1967.

Dahlstrom, C. D. A., Structural geology in the eastern margin of the Canadian Rocky Mountains, Bull. Can. Pet. Geol., 18, 332-406, 1970.

Dèbat, P., Essai sur la déformation des gneiss de la Montagne Noire occidentale, thèse, Univ. Toulouse, Toulouse, France, 1974.

Dunnet, D., A technique of finite strain analysis using elliptical particles, Tectonophysics, 7, 117-136, 1969.

Dunnet, D., and A. W. B. Siddans, Non-random sedimentary fabrics and their modification by strains, Tectonophysics, 12, 307-325, 1971.

Engelder, T., and R. Engelder, Fossil distortion and décollement tectonics of the Appalachian Plateau, Geology, 5, 457-460, 1977.

Escher, A., J. C. Escher, and J. Watterson, The reorientation of the Kangamiut dyke swarm, West Greenland, Can. J. Earh. Sci., 12, 158-173, 1975.

Furtak, H., Die 'Brechung' der Schiefrigkeit, Geol. Mitt., 2, 177-196, 1962.

Furtak, H., Die Tektonik der unterdevonischen Gesteinsfolge im deutschbelgisch-luxemburgischen Grenzgebiet., Geol. Mitt., 4, 273$332,1965$.

Furtak, H., and E. Hellermann, Die tektonische Verformung von pflanzlichen Fossilien des Karbons, Geol. Mitt., 2, 49-69, 1961.

Gairola, V. K., Deformed nummulites from Dogadda area, Garhwal, Himalaya, Bull. Earth. Sci., 4/5, 69-71, 1976.

Gilluly, J., Tectonics involved in the evolution of mountain ranges, in The Nature of the Solid Earth, edited by E. C. Robertson, pp. 406439, McGraw-Hill, New York, 1972.

Graham, R. H., Quantitative deformation studies in the Permian rocks of Alpes Maritimes, in 'Goguel' Symposium, pp. 219-238, Bureau de Recherches Geologiques et Minieres, Orleans, France, 1978.

Groshong, R. H., Jr., Strain fractures and pressure solution in natural single layer folds, Geol. Soc. Am. Bull., 86(10), 1363-1376, 1975.

Harker, A., On Slaty Cleavage and Allied rock-structures, with special reference to the Mechanical Theories of their Origin, $B r$. Assoc. Adv. Sci. Rep., 813-852, 1885.

Heard, H. C., Comparison of the flow properties of rocks at crustal conditions, Philos. Trans. R. Soc. London Ser. A, 283, 173-186, 1976.

Hicks, S. D., and W. Shofnos, The determination of land emergence from sea level observations in southeast Alaska, J. Geophys. Res., 70, 3315-3319, 1965.

Johnston, M. J. S., A. C. Jones, and W. Daul, Continuous strain mea- 
surements during and preceding episodic creep on the San Andreas fault, J. Geophys. Res., 82(36), 5683-5691, 1977.

Langheinrich, G., Die tektonische Deformation von Schellwienella umbraculum im Givet von Niedersalwey (Westfalen), Geol. Mitt., 7, 159-172, 1967a.

Langheinrich, G., Die Bestimmung der tektonischen Gesteinsdeformation mit Hilfe deformierter Ammoniten; mit zwei Beispielen aus den Allgäu-Schichten (Jura-Fleckenmergeln) Oberbayems und Tirols, Noves Jahrb. Geol. Palaeont. Monatsh., I28, 275$293,1967$.

Le Corre, C., and B. Le Theoff, Zonéographie de la deformation finie, de la fabrique et du métamorphism dans un ségment de la chaîne hercynienne armoricaine, Bull. Soc. Géol. Fr., 17, 1435-1442, 1976.

Le Théoff, B., Marqueurs ellipsoidaux et déformation finie, thèse, Univ. de Rennes, Rennes, France, 1977.

McLeish, A. J., Strain analysis of deformed pipe rock in the Moine thrust zone, northwest Scotland, Tectonophysics, 12, 469-503, 1971.

Mukhopadhyay, D., and Bhattacharya, S., A study of pebble deformation in the Precambrian rocks of Singhbhum District, Bihar, $J$. Geol. Soc. India, 10, 77-87, 1969.

Mukhopadhyay, D., S. Sengupta, and S. Bhattacharya, Strain measurements in some Precambrian rocks of eastern India and their bearing on the tectonic significance of schistosity, J. Geol., 77, 703$710,1969$.

Nadai, A., Theory of Flow and Fracture of Solids, vol. I, 572 pp., McGraw-Hill, New York, 1950.

Nickelsen, R. P., Fossil distortion and penetrative rock deformation in the Appalachian Plateau, Pennsylvania, J. Geol., 74, 924-931, 1966.

Pfiffner, O. A., Tektonische Untersuchungen im Infrahelvetikum der Ostschweiz, Mitt. geol. Inst. Eidg. Tech. Hochsch. Univ. Zürich, 217, 432 pp., 1977.

Pfiffner, O. A., Der Falten- und Kleindeckenbau im Infrahelvetikum der Ostschweiz, Eclog. Geol. Helv., 71(1), 61-84, 1978.

Plessmann, W., Laterale Gesteinsverformung vor Faltungsbeginn im Unterkarbon des Edersees (Rheinisches Schiefergebirge), Geol. Mitt., 5, 271-284, 1965.
Price, N. J., Rates of deformation, J. Geol. Soc. London, 13I, 553-575, 1975.

Ramberg, H., Superposition of homogeneous strain and progressive deformation in rocks, Bull. Geol. Inst. Univ. Uppsala, 6, 35-67, $1975 a$.

Ramberg, H., Particle Paths, displacement, and progressive strain applicable to rocks, Tectonophysics, 28, 1-37, 1975b.

Ramsay, J. G., Folding and Fracturing of Rocks, 568 pp., McGrawHill, New York, 1967.

Ramsay, J. G., and R. H. Graham, Strain Variations in shear belts, Can. J. Earth Sci., 7, 786-813, 1970.

Ramsay, J. G., and D. Wood, The geometric effects of volume changes during deformation processes, Tectonophysics, 16, 263-277, 1973.

Roberts, J. C., Deformed nodular concretions from the Upper Dalradian of eastern Inishowen, Co. Donegal, Irish Nat. J., 17, 403-407, 1973.

Schmid, S. M., The Glarus overthrust: Field evidence and mechanical model, Eclog. geol. Helv., 68(2), 247-280, 1975.

Sorby, H. C., On the origin of slaty cleavage, Edinburgh New Philos. J., 55, 137-148, 1853.

Tan, B. K., Determination of strain ellipses from deformed ammonoids, Tectonophysics, 16, 89-101, 1973.

Trümpy, R., Ueber die Geschwindigkeit der Krustenverkürzung in den Zentralalpen, Geol. Rundsch., 61(3), 961-964, 1972.

Trümpy, R., The timing of orogenic events in the central Alps, in Gravity and Tectonics, edited by K. A. DeJong and R. Scholten, pp. 229-251, John Wiley, New York, 1973.

Whitten, C. A., Crustal movement in California and Nevada, Eos Trans. AGU, 37(4), 393-398, 1956.

Wickham, J. S., An estimate of strain increments in a naturally deformed carbonate rock, $A m . J . S c i ., 273,23-47,1973$.

(Received December 3, 1979; revised August 18, 1980; accepted July 30, 1981.) 